\title{
Correction to: Determining the effects of trastuzumab, cetuximab and afatinib by phosphoprotein, gene expression and phenotypic analysis in gastric cancer cell lines
}

Karolin Ebert ', Gwen Zwingenberger', Elena Barbaria', Simone Keller ${ }^{1}$, Corinna Heck', Rouven Arnold ${ }^{1}$, Vanessa Hollerieth ${ }^{1}$, Julian Mattes ${ }^{2}$, Robert Geffers ${ }^{3}$, Elba Raimúndez ${ }^{4,5}$, Jan Hasenauer ${ }^{4,5,6}$ and Birgit Luber ${ }^{1 *}$

Correction to: BMC Cancer 20, 1039 (2020) https://doi.org/10.1186/s12885-020-07540-7

Following publication of the original article [1], the authors reported an error in the labeling of Table 5. The corrected Table 5 is given below.

The original article can be found online at https://doi.org/10.1186/s12885020-07540-7.

* Correspondence: birgit.luber@tum.de

${ }^{1}$ Fakultät für Medizin, Technische Universität München, Klinikum rechts der Isar, Institut für Allgemeine Pathologie und Pathologische Anatomie, 81675 München, Germany

Full list of author information is available at the end of the article

(c) The Author(s). 2020 Open Access This article is licensed under a Creative Commons Attribution 4.0 International License, which permits use, sharing, adaptation, distribution and reproduction in any medium or format, as long as you give appropriate credit to the original author(s) and the source, provide a link to the Creative Commons licence, and indicate if changes were made. The images or other third party material in this article are included in the article's Creative Commons licence, unless indicated otherwise in a credit line to the material. If material is not included in the article's Creative Commons licence and your intended use is not permitted by statutory regulation or exceeds the permitted use, you will need to obtain permission directly from the copyright holder. To view a copy of this licence, visit http://creativecommons.org/licenses/by/4.0/ The Creative Commons Public Domain Dedication waiver (http://creativecommons.org/publicdomain/zero/1.0/) applies to the data made available in this article, unless otherwise stated in a credit line to the data. 
Table 5 Candidate genes involved in phenotypic response to afatinib treatment

\begin{tabular}{|c|c|c|c|c|c|c|c|c|c|}
\hline \multicolumn{10}{|c|}{ a) Genes potentially involved in reduction of motility after afatinib treatment } \\
\hline $\begin{array}{l}\text { SERPINE1 } \\
\text { HBEGF }\end{array}$ & $\begin{array}{l}\text { F3 } \\
\text { ITGA2 }\end{array}$ & $\begin{array}{l}\text { CXCL8 } \\
\text { HAS2 }\end{array}$ & $\begin{array}{l}\text { PLPP3 } \\
\text { SPRY2 }\end{array}$ & F2RL1 & PTGS2 & CYR61 & CXCL1 & SEMA6D & ETS1 \\
\hline \multicolumn{10}{|c|}{ b) Genes potentially involved in induction of apoptosis after afatinib treatment } \\
\hline$B A X$ & BBC3 & BCLAF1 & CAV1 & E2F1 & FADD & FAF1 & FAS & GSN & HYAL2 \\
\hline IL19 & IL2ORA & INHBB & LCK & LGALS9 & NACC2 & NF1 & NFATC4 & NKX3-1 & PAK2 \\
\hline PARK7 & PDCD5 & PDIA3 & PEA15 & PPIF & $P P P 2 R 1 B$ & РРРЗСС & PRKRA & SFN & SFPQ \\
\hline SKIL & SLC9A3R1 & SMAD3 & STK4 & TGFBR1 & TP73 & TPD52L1 & $Y W H A B$ & YWHAE & YWHAG \\
\hline YWHAH & YWHAQ & YWHAZ & ZNF205 & & & & & & \\
\hline
\end{tabular}

Genes that were regulated in MKN1 cells after $4 \mathrm{~h}$ afatinib and trastuzumab + afatinib treatment and were assigned to the biological function "positive regulation of cell motility" were selected (a). Genes that were regulated in NCI-N87 but not in MKN1 and MKN7 cells after $24 \mathrm{~h}$ afatinib and trastuzumab + afatinib treatment and were assigned to the biological function "positive regulation of apoptotic signaling pathway" were selected (b). Italics typeface indicates downregulation and bold typeface upregulation

The original article [1] has been corrected.

\section{Author details}

${ }^{1}$ Fakultät für Medizin, Technische Universität München, Klinikum rechts der Isar, Institut für Allgemeine Pathologie und Pathologische Anatomie, 81675 München, Germany. ${ }^{2}$ MATTES Medical Imaging GmbH, A-4232 Hagenberg, Austria. ${ }^{3}$ Helmholtz Zentrum für Infektionsforschung, 38124 Braunschweig, Germany. ${ }^{4}$ Helmholtz Zentrum München-German Research Center for

Environmental Health, Institute of Computational Biology, 85764 Neuherberg, Germany. ${ }^{5}$ Center for Mathematics, Technische Universität München, 85748 Garching, Germany. ${ }^{6}$ Faculty of Mathematics and Natural Sciences, University of Bonn, 53113 Bonn, Germany.

Published online: 23 November 2020

\section{Reference}

1. Ebert $\mathrm{K}, \mathrm{Z}$ wingenberger $\mathrm{G}$, Barbaria $\mathrm{E}$, et al. Determining the effects of trastuzumab, cetuximab and afatinib by phosphoprotein, gene expression and phenotypic analysis in gastric cancer cell lines. BMC Cancer. 2020;20: 1039 https://doi.org/10.1186/s12885-020-07540-7. 